\title{
Our Moon has Blood Clots and the Poetics of Indigenous Representation: Kashmiri Pandit Narratives as Indigenous Literature
}

\section{Soumyadeep Neogi}

Senior Research Fellow, Department of English, University of Delhi, India.

Mail Id: soumyadeepneogi89@gmail.com | Orcid ID: 0000-0001-8634-2244

\begin{abstract}
As the literature of marginalized communities, Indigenous Literature contests mainstream discourses through self-representation and depictions of critical indigenous issues. No matter where it is produced, Indigenous Literature is connected by certain universal characteristics and thematic similarities that display indigenous people's resistance to socio-cultural hegemony. Thus, it is a literary response to contexts of oppression and discrimination and engenders a collective legacy of social suffering by expressing historically suppressed truths. It disputes political dominance with themes that articulate the indigenous fight for personal, social, political and cultural identity. The relationship between people and place, and the experience of losing one's homeland and severing ties from one's traditions is a crucial part of Indigenous Literature. Kashmiri Pandits are not generally considered an 'indigenous community,' but recent Pandit narratives reflect similar concerns regarding their experiences of facing targeted violence, losing their homeland and being forced into exile after the insurgency started in Kashmir. This paper seeks to situate Pandits as an indigenous community, and by analysing Rahul Pandita's representation of the Pandit experience in Our Moon has Blood Clots, the paper extends the scope of Indigenous Literature in contemporary Indian English Literature to include recent Anglophone Kashmiri Pandit narratives.
\end{abstract}

Keywords: Indigenous Literature, Autochthony, Kashmiri Pandit, Kashmir Conflict, Indian English Literature

\section{Introduction}

\section{Positioning Kashmiri Pandits as an Indigenous Community}

As a generic term, 'indigenous people' is used in different countries to refer to the First Nations, Native American, Maori, Aboriginal and Adivasi communities; and till date, no international consensus has been achieved on the specific definition of 'indigenous people.' While 
social-science scholars use the term to describe people who follow a 'traditional' lifestyle that is different from modern Western living standards (Gosart 89), most international organizations agree that indigenous people are ethnic communities who are descendants of the historically native inhabitants of a specific region but do not constitute the dominant demography there presently (WHO; UN; UNPFII), and who have a distinct culture which is intrinsically linked with the natural environment of the region; indigenous communities lead lives that are socially, culturally, politically, linguistically and economically different from the dominant group (Coates 8). The World Health Organization (WHO) specifies that indigenous people may live "within, or are attached to" these regions, which means that even if they presently stay away from the region, they still qualify as an indigenous community for that region - thus, present physical location is not a factor in determining the indigenous identity of an individual or community. The WHO and the United Nations (UN) also stress on the principle of self-identification and assert that indigenous people "identify themselves as being part of a distinct cultural group, descended from groups present in the area before modern states were created and current borders defined" (WHO; UN). The United Nations Commission on Human Rights and the United Nations Economic and Social Council add that marginal groups of a society/region should also be grouped under 'indigenous people' if the dominant social and cultural structures of their native land are alien to their traditional culture (Coates 7), even if they did not suffer conquest or colonization as long as they are descendants of communities who inhabited the region when the dominant groups arrived. Indigenous people have a "special relation" with their traditional/ancestral land which is of "fundamental importance for their collective physical and cultural survival" and they are determined to "maintain and reproduce their ancestral environments and systems as distinctive peoples and communities" (UN). According to Ken Coates, indigenous people have "historical societies with a strong understanding of the past, often passed on through oral testimony, ceremonies and cultural activities," he adds:

They view their experience from a very long perspective ... devoting a great deal of community time to the remembrance of ancestors and important events and processes. The sense of rootedness in the past is highlighted by the attachment of stories and legends to traditional lands and to the richness and texture of indigenous languages, both of which play a vital role in preserving the indigenous understanding of history. (Coates 14)

The criterion of having a historical continuity with their territories is crucial to indigenous people who consider themselves different from the other communities who prevail in those territories now as the dominant group; hence, they are determined to preserve their cultural systems and transmit it to their future generations (Coates 6). Indigenous people, all over the world, share certain common concerns like political neglect, economic marginalization and social vulnerability with regards to the protection of their cultural rights, recognition of their distinctive identities and rights to traditional resources and lands" (UNPFII). The strict adherence to traditional social 
systems ensured their exclusion from the dominant political system; hence, indigenous people "lack political power and autonomy" and are dominated by other groups (Coates 2). Following these internationally recognized characteristics, this paper would first situate the Kashmiri Pandit community of India within the category of 'indigenous people' then by analyzing Rahul Pandita's Our Moon has Blood Clots, argue that Kashmiri Pandit Narratives fall under the scope of Indigenous Literature.

In India, there is no official recognition of the concept 'indigenous people' (IWGIA), although the terms 'Adivasis' (original inhabitants) and 'Vanavasis' (forest dwellers) have been popularly used to refer to indigenous populations, and the government categorizes these ethnic communities as Scheduled Tribes. The Kashmiri Pandits make up the Hindu religious minority community of the predominantly Muslim Kashmir valley and are historically the original inhabitants of the region (Tripathi 1, Baig). The community satisfies the criteria mentioned above and can be categorized as 'indigenous people' because Kashmiri Pandits are the ethnic descendants of the original Shaivite Saraswat Brahmin inhabitants of Kashmir going back hundreds of years (Kaw 183). They have a unique socio-cultural tradition and prominent Pandits from antiquity like Kalhana, author of Rajatarangini, and Abhinavagupta, author of Abhinavabharati, have contributed immensely to Indian scholarship. Despite facing significant oppression from foreign invaders in the last seven hundred years during which their population reduced drastically, the minuscule Pandit community have tried maintaining strong cultural ties with the Kashmir valley (Essa). As a community, the Pandits have suffered from external conquests (Kaw 91) and have faced political and social marginalization by the dominant Kashmiri Muslim community. The marginalization reached its zenith during the late 1980s when militancy erupted in Kashmir and Pandits were selectively threatened, targeted, raped and brutally killed (EFSAS). ${ }^{1}$ The lack of security forced most from the anguished community into exile in the early 1990s, as they moved to neighbouring Jammu and other Indian states (Bamzai 254). The Pandit population in the Valley was 5 percent in 1950, but presently only about three thousand Pandit families (less than 1 percent) remain there (Zutshi 318). However, the community has maintained a historical continuity with Kashmir. Recent Pandit narratives reflect the importance of this traditional land for their cultural survival and hence, their insistence on following traditional cultural practices even if they are no longer in Kashmir because they still proudly assert their identities as Kashmiri Pandits. Thus, the Kashmiri Pandit community demonstrates all the internationally recognized parameters to be categorized as 'indigenous people.' Their exodus from the Valley is mired in political blame-game but most scholars agree that the community suffered an ethnic cleansing; consequently, becoming the "invisible and inaudible" victims of the conflict (Nandy 171). One plausible reason for their targeting was the Pandits' political affiliation; their ultimate loyalty was with India and they "could not identify" with the "anti-India uprising" of the

${ }^{1}$ For more information on the socio-political conditions leading to the Kashmiri Pandit exodus during the start of the insurgency, read the EFSAS report. 
dominant Muslim community (Bose 136). Hence, they were seen as Indian agents and spies who needed to be eliminated. But, Kashmiri Separatist leaders, like Syed Ali Shah Geelani, have always denied that any such ethnic cleansing took place, and insisted that the Pandits left Kashmir on their own after the government promised them financial benefits (Hakeem 68, 72).

The Pandits have been in exile for thirty years now. In the last decade, many Pandit authors have expressed through Anglophone literature their anguish at the loss of their homeland, culture and identity. Authors like Rahul Pandita, Arvind Gigoo, Varad Sharma and Siddhartha Gigoo have articulated the angst of the Pandit community and laid bare the tale of their suffering to a global audience. Their texts are critical for a holistic understanding of the Kashmir conflict. The narratives display the characteristic features of 'Indigenous Literature' and hence, should be regarded as a distinct genre of Indigenous Literature within the Indian English literary canon. Rahul Pandita's memoir Our Moon has Blood Clots is particularly important, in this regard, as it demonstrates several key concerns that plague the Pandit community and a textual analysis shall reveal how Pandit narratives qualify as 'Indigenous Literature.' However, before commencing with the analysis it is imperative to first outline the distinctive features of Indigenous Literature.

\section{Poetics of Indigenous Literature}

Indigenous Literature, hereafter referred to as I.L., is not fully explored to its diverse potencies because of its vacillating position in literary history (Abt 171). However, no matter which indigenous community produces it and where it is produced I.L. has certain common features. Broadly speaking, I.L. refers to a "special group of literary writing based on the ethnic identity of the writers" and for an author to be regarded as an indigenous writer, he or she needs to demonstrate strong "cultural competence" and highlight the "indigenous otherness" to counter "mainstream culture" (Chiu 1074). The notion of "indigeneity" signifies "cultural otherness" and I.L. positions itself as the "other" by reflecting the collective consciousness of a community to challenge hegemony and reconstruct identity (Chiu 1074- 1084). Teresa Podemska Abt observes that I.L. provides "language to ... political oppression" and expresses "historical truths" by selfrepresenting "crucial Indigenous issues" in English and situating them within "sociocultural political systems." These texts have themes that depict socio-historical experiences of suffering and "dispute political dominance" by highlighting the "Indigenous fight for a personal, cultural, social and political identity." She adds that I.L. produces a "collective legacy of social suffering" and articulates historical trauma; hence, it also serves as a literature of "resistance and protest" that is devoid of any other "literary, aesthetic ... or imaginative functions" (Abt 171). Michele Lacombe agrees that I.L. can be regarded as resistance writing as it presents "aspects of cultural continuity and ... new methods of cultural revitalization" (Lacombe 256). Joshua B. Nelson asserts that I.L. reflects the "abiding relationship between people and place ... a home cherished, longed for, or irrecoverable," and explores whether traditional relationships with a place can be maintained "in the aftermath of removal [from the land]" (Nelson 29, 30). He observes that I.L. 
emerges from a sense of political responsibility and articulates the indigenous community's "struggles against systematic marginalization by the dominant social structures" (Nelson 32). Similarly, Armand Garnet Ruffo notes that I.L. is a "call for liberation" as it portrays racism, marginalization and the "realities of what it means to be a people under siege," it functions as their "collective voice" and strives to bring change in a society that does not "share their values and concerns" (Ruffo 663-64, 670). Like Abt, Ruffo also argues that indigenous writers serve as the "identity and voice" of their indigenous community and "break" their silence (Ruffo 669-70). Thus, I.L. shapes "its own sociocultural and aesthetic values" and assuredly delivers it to both the mainstream and the global audience, which makes this genre fall within the scope of world literature rather than be the literature of one country or region (Abt 171).

These are the essential characteristics of Indigenous Literature and in the following section, a textual analysis of Rahul Pandita's memoir is undertaken to show how it emerges as an indigenous literary text.

\section{Locating Our Moon has Blood Clots as Indigenous Literature}

Several indigenous activists have argued that to recover their identities, indigenous people had to reestablish their connection with their indigenous cultures. In answering this call, many Kashmiri Pandit writers have started to write about the concerns of their community from their own experience, and have sought to pass down this knowledge to other members of their community and their descendants. Rahul Pandita's memoir Our Moon has Blood Clots: The Exodus of Kashmiri Pandits (2013) is a seminal text that deals with the ordeals of the Pandit community, where the author has narrated his own experience of being forced to leave his own homeland and consequently, live in exile. The text depicts the delicate position of the minority Pandit community after India's independence and portrays the atmosphere of terror that had engulfed their lives in 1989-90 when militancy broke out in Kashmir and demanded secession from India. Pandita declared in an interview that the text "sets the record straight for the first time" and presents the Pandit viewpoint vis-à-vis the Kashmir conflict because the "liberal discourse ... and the media" had "bypassed" their story and "relegated [it] to the margins" (Griffin). The text also counters the claims made by the Kashmiri Muslim authors like Basharat Peer, and Mirza Waheed who sought to highlight the perspectives of the Kashmir's majority Muslim community in their texts Curfewed Night and The Collaborator where the lack of an indigenous Pandit voice is apparent. Pandita brings the suppressed, silenced voices of Pandits into mainstream literature; he is bold and uncompromising in his portrayal of the violence and the trauma which the Pandit community went through during their ethnic cleansing. The narrative is emotionally charged, full of pain and anger as it reflects the Pandit community's hopelessness, rootlessness and homelessness. The following sections present three crucial aspects of Pandita's portrayal which qualify the text as an indigenous literary text. 


\section{Prevalent Conditions of Marginalization and Violence leading to the Exodus}

Portraying oppression suffered at the hands of the dominant community is one of the prime concerns of Indigenous Literature. Through the narrator's personal experiences which he cannot repress, the text highlights the precarious social position that Pandits were in before the militancy began in the 1980s. The memories of these experiences envelope Pandita's whole existence and traumatize him. Scenes from Pandita's family life in Srinagar - the month-long Hindu religious festival of Shivratri, the trips to the Shankaracharya and Kheer Bhawani temple, their big house and the vegetable garden around it - form his most fond memories. They reflect not only the importance of Kashmir in the Pandit consciousness, but also signify the cherished qualities of a home which are now lost to them - familiarity, comfort, security, tradition and rootedness. But, the narrative reveals that all these happy memories were overshadowed by incidents that made Pandita aware of his position as an unwanted religious minority and the socially marginalized 'other;' for instance, being teased by friends at school for singing the Indian national anthem or being threatened for supporting the Indian cricket team (Pandita11, 41). Pandita describes a "thumb rule" that guided their lives, a parable handed down through generations of Pandits like a cultural memory, which claimed that a Pandit can never win and was always supposed to lose to a Muslim (Pandita25). The effect of these cultural memories is significant in the young child's psyche, it shattered his self-esteem and he refused to wear the sacred thread of Brahmins because it would identify him as a Hindu and then his friends would always be able to overpower him (Pandita26).

The murder of a Pandit political activist Tika Lal Taploo in 1989 scared the Pandits who were afraid to go out of their houses alone. Children were barred from playing outside as random killings and kidnappings of Pandits started (Pandita51). The situation was getting increasingly tense, leading to the night of 19th January 1990 when loudspeakers from every mosque in Kashmir, blared out warnings for the Pandits to leave the valley amidst loud cheers (Pandita58). Three options were historically given to them - "Raliv, Chaliv, yaGaliv" - to abandon their religion and stay or to leave Kashmir or get killed (Pandita18). Pandita observes that often neighbours and friends collaborated with the militants, believing that Pandits would flee out of terror if a few of them were killed. Pandita reflects upon how his family believed that the violence would soon subside and that it was a passing phase (Pandita 55), but the night of $19^{\text {th }}$ January changed everything when fear gripped their entire community - "All is not well. Everything is going to change..." (Pandita 58). The narrative details how terrified Pandits shut themselves up and huddled together during the night as calls for secession and threats to the Pandits were issued by mobs outside - "They rushed towards us like poison darts ... The crowd wanted to turn Kashmir into Pakistan, without the Pandit men, but with their women." The Pandits were convinced that it was just a matter of minutes before the crowd would barge into their homes and kill them, 
Pandita's mother took a long kitchen knife and planned to kill her daughter first and then herself to the utter disbelief of his father. The young boy could not comprehend what was happening as his entire life flashed before his eyes - "We are very scared ...Where would we run away to? Would Ma have to kill herself? What about my sister?" (Pandita 59). The narrative informs that often Pandits were forced to take part and even lead such processions to ensure that if paramilitary forces fired then the Pandits would die first. Militants also issued hit-lists in neighbourhoods and advertisements in newspapers ordering Pandits to leave or get killed and numerous such targeted killings did take place (Pandita 86). It was one such hit-list that was pasted outside the author's home which convinced the Pandita family to finally leave their home and leave Kashmir altogether (Pandita70). Thus, the narrative articulates the prevalent condition of marginalization, insecurity and violence which had forced thousands of Pandit families to leave their traditional homeland in the early months of 1990 after the militancy intensified in Kashmir.

\section{Loss of Home and Life in Exile}

Indigenous literary works always articulate the effects of losing their traditional homeland on the indigenous community. Pandita's text does this by depicting the physical and psychological ordeals of the Pandits during their life in exile. ni egufer thguos dah stidnaP eht fo tsoM retfa ummaJ their exodus and the text reveals how their lives were drastically transformed there. In Jammu, Pandita saw thousands of terror-stricken Pandits who had a certain void and blankness in their eyes. Families that had rivers flowing through their fields now had no access to freshwater "It took us a while to understand that the water that came out of taps in Jammu and elsewhere was not fresh water" (Pandita74). Pandits were huddled into makeshift camps and forced into poverty; they had to depend on government doles to sustain themselves. The narrator's family lived in refugee camps and cheap hotels before finally moving to a one-room flat on rent. Despite the difficulties in Jammu, Pandita maintains that it was safer, unlike Kashmir where survival was their only concern amidst communal slogans, threats, hit-lists, and murders (Pandita75). He conveys the sense of loss pervaded the Pandit consciousness in Jammu - "We had lost everything - home, heath ... which had taken generations to build" (Pandita76). In spite of their best efforts, the lives of Pandits never got any better within the refugee camps at Jammu where up to five people had to share one small room (Dabla 78). Many elderly people could not cope with their new alien surroundings and the overwhelming memories of their former homeland and developed Alzheimer's disease which eventually killed them. The Kashmiri sociologist Bashir Ahmad Dabla observes that older and disabled people suffered most in exile as they could tolerate the extreme heat of Jammu and many collapsed or died from dehydration, heat-strokes, neurological ailments and cardiac attacks (Dabla 81). Pandita describes the situation as:

It was a pathetic existence. Many fell ill with diseases that were hitherto unknown to the community ... elderly people died of sunstroke ... and scorpion bites. Children became infected with fungal diseases, and scabies became rampant in the unhygienic 
camps. Doctors reported hundreds of cases of stress-induced diabetes. Heart disease and hypertension made their way in our lives. Many fell into depression ... Medical surveys ... said that the Kashmiri Pandits in exile had aged by ten to fifteen year. (Pandita 97)

His own mother would injure herself from lifting countless buckets of water each day, and had to take two months of bed rest before resuming her work. Privacy was a big issue for Pandits in Jammu as families had to live together in small rooms or refugee camps. Pandita would hang a sheet in their room to create a separate space for himself and imagine that he was in his "first-floor room back home in Srinagar, in the room with the wooden bookshelf" (Pandita 100).

Pandita mentions that their immovable properties in Kashmir were also usurped by the state government under various pretexts, and several Pandit homes, farms and temples were either demolished or erased from government records. Middlemen from Kashmir made rounds of the refugee camps in Jammu trying to coax the Pandits to sell their homes at dirt-cheap rates and given the acute financial crisis that they were in, several Pandits consented to sell their houses which they had so lovingly built (Pandita 104). His family also had to sell off their family home in order to meet the medical expenses of his mother's treatment in Ludhiana. Although he regards this as a sign of permanent exile for the Pandits from Kashmir, Pandita admits that the community had no other choice because they had medical and other expenses to cover and most of their houses had already been vandalized or burnt down (Pandita 105).

The real tragedy of losing his homeland and being in exile affects Pandita when he moves to Delhi and observes that, like him, thousands of migrants arrive there every day to begin a new life. However, what makes him different is that while the rest had a home to return to with their loved ones waiting, he was a "permanent exile" and could never return to his home in "the Kashmir Valley where my family came from" (Pandita 10). The narrative explicates how for Pandits, their home could only be in Kashmir where their roots lay. The text reveals the hopelessness, despair and agony of the Pandit community in exile where they suffered from both an existential and an identity crisis. The thought of being homeless haunts them forever, as Pandita observes how his old mother acquired the habit of telling everyone she met, "Our home in Kashmir had twenty-two rooms" (Pandita 13). Much to his irritation, the old lady would narrate their tales of persecution to everyone she met but Pandita realizes that this was for her to channelize her trauma and it was "the only thing that reminded her of who she was" (Pandita 12). Living in exile hurt their pride because these people were quite affluent in Kashmir, but now they were destitute and forced to live in small one-room flats. Pandita's father was also affected and even after years of being in exile, he would get excited whenever he saw Kashmir on television and imagine that they still had access to their lost homeland (Pandita 27). He fondly referred to Srinagar as "Shahar - the city that is home;" and if Pandita reminded him that they were in Delhi, the old man would just give an "embarrassed smile" before going silent for several days 
(Pandita29). The "mere mention" of the word "Shahar" evokes in the old man images of his homeland, his beautiful house and his old life, so silence was the only way for him to deal with the present situation and accept the reality that everything was now lost.

Pandita describes exile as a "dull throbbing pain" (Pandita 38), he confesses that he is grateful that barring his parents, none of the other older members of his family had "lived to experience the pain and difficulties of living in exile" (Pandita 47). Thus, the narrative highlights the love that Pandits feel for Kashmir even after years of staying away and the psychological trauma that continues to affect them. An entire generation was forced to rebuild their lives elsewhere, yet Shahar was still their "jugular vein" (Pandita 29). Teng and Gadoo observe that Pandits loved Kashmir with a "greater spiritual commitment" than the Muslims because they were the indigenous people of the region who followed its indigenous culture for generations over "thousands of years" (Teng and Gadoo82). Pandits had a strong sense of belonging in Kashmir where their roots firmly lay because they were not conquerors but children of the soil (Teng and Gadoo 82).

\section{Loss of Culture}

One of the prime concerns of all Indigenous Literature is to emphasize the loss of the traditional culture of the indigenous community like, in this text, Pandita laments the loss of the unique Kashmiri Pandit culture during their life in exile. The title of the text - Our Moon has Blood Clots - reflects this sense of loss; their memories, customs and traditions are now stained with blood and sadness. For the Pandits, the memories of their rituals and traditions do not signify joy but evoke trauma and serve as a reminder of their sufferings. The image of the moon, in the title, alludes to one of the most important religious rituals of the Pandit community - the celebration of Saraswati Puja on a full moon night. However, their historical circumstance has tarnished this sacred memory, causing the moon to appear bloodstained as a symbolic sign of all the violence they had endured as a community. The image of the "clot" signifies that their wounds have not yet healed and are still very much open. The image of the moon is also, traditionally, a symbol of pristine beauty; but for the Pandit community, this eternal image of beauty is stained with memories of violence which cannot be washed away. The narrative depicts the impact of the loss of cultural heritage by suggesting that the use of the native Kashmiri language was gradually reducing within the Pandit community in exile. Pandita realizes that the true significance of his traditional homeland is that it is the only region where he could speak in his mother tongue. He notes that speaking in one's mother tongue fills "one with contentment and an undefinable happiness," and it was a liberating experience for him to speak in Kashmiri when he later travelled to Srinagar on journalistic assignments (Pandita 36).

The real fear that Pandita has is that, after decades of being in exile, for the younger generation of Kashmiri Pandits, Kashmir is getting reduced to just a "memory" and an "overdose 
of nostalgia" because they had to move on. Now, their traditional homeland is just a "calendar" hanging in the room, a traditional dish cooked during religious festivals, or a marriage ceremony "that the elders insist must be solemnized in Jammu." When Pandita meets his Pandit friends who are all well-settled now, they still sing Kashmiri songs but a lot of them were "too young to remember anything of Kashmir." However, a "rush of memory" would often affect them and they would call him from faraway places for no other reason but just to "talk to someone in Kashmiri." Language here functions both as a way of retaining the lost heritage and also to channel out traumatic memories. For the new generation of Pandits who grew up outside Kashmir, their "homes" were elsewhere; hence, Pandita is skeptical whether their identity and the "story" of their community would eventually be lost in the next few decades. He admits that the previous generation was responsible for keeping alive their indigenous customs and traditions and "created mini Kashmirs wherever they settled," but "after them, there will be nobody left to remember" (Pandita 153). Pandita laments:

We are losing our tradition, our links to the place where we came from. This is evident during weddings, or when someone dies. Tradition is like an embarrassing grandparent who needs to be fed and put back to bed in a back room. (Pandita153-4)

He gives an instance from his own life to highlight this cultural setback, he describes how helpless he felt when his uncle had died and they could not locate a priest who knew the proper Pandit funerary rituals and so they settled for a local priest and recited whatever prayers they could: "At least the dead merit dignity; their farewell ought to be performed in the same manner as that of their forefathers" (Pandita154). Thus, the narrative portrays the loss of indigenous culture in the Pandit community. Pandita makes a case for cultural revivalism within the Pandit community when he states that during his numerous journalistic trips to Kashmir, he felt "connected" to his ancestors there and realized that it was "important to be in touch with one's roots" (Pandita 155).

\section{Qualifying the Text as Indigenous Literature}

Rahul Pandita foregrounds some of the most pressing issues that affect the Kashmiri Pandit community, from the loss of their homeland to the loss of their cultural identity in the future. Thus, the text demonstrates thematic and expressional qualities which connect it to the larger body of Indigenous Literature (I.L.) from all over the world. Teresa Abt observes that though I.L. is positioned as minority literature and given an "inferior ... and secondary status," yet it portrays important topics like "oppression and discrimination." For Abt, I.L is a literary response that counters mainstream misrepresentations and deconstructs "cultural and social stereotypes" (Abt173). Ruffo adds that discourse shapes historical truth; and hence, "misrepresentation and appropriation" of the indigenous voice should be contested or else alternative narratives will not emerge (Ruffo 666). Pandita's narrative does precisely this and functions as an alternative narrative to counter the privilege given to political discourses and narratives of the dominant community. Within the sphere of modern 
Anglophone Kashmiri literature, narratives by authors belonging to the dominant community, like Basharat Peer and Mirza Waheed, enjoy greater privilege and this marginalizes the Kashmiri Pandit perspective on the conflict but Pandita counters these mainstream portrayals. The text bridges a critical gap within the mainstream academic discourse on the Kashmir issue by voicing the standpoint of the indigenous Pandit community. It addresses the global audience and brings to their attention the exact circumstances of the Pandits after they were forced to leave their traditional homeland. The text also serves as a testament for future generations of Pandits, to inform them about the legacy and history of their community. Pandita highlights the universal resistance to hegemony and cultural dominance which I.L. seeks to accomplish and hence, the text qualifies as an indigenous literary text.

Some of the key features of I.L. found in the text are the depictions of the annihilation of the Pandit community's culture in their homeland, the systematic oppression that they suffered at the hands of the dominant community there, the transmission of intergenerational trauma within the community, the psychological trauma of losing their homeland, the new diseases that affect them because of this dislocation from the homeland, and the gradual erosion of their distinct identity both within and outside Kashmir. The text tries to reclaim this lost identity and restructure it for future generations so that their story is not forgotten by the world.

\section{Conclusion: Kashmiri Pandit Narratives as Indigenous Literature}

Narratives by other Kashmiri Pandit authors like Siddhartha Gigoo, Varad Sharma, Sudha Kaul, et cetera also demonstrate these themes of rootlessness and oppression. These narratives have emerged as a literary response to the misery that was imposed on the community after their lives had been turned upside down. The very survival of the Pandit community was at peril during the late 1980s and now, it is their cultural identity that faces an existential threat after years of drudgery and poverty. The media and the mainstream discourse on Kashmir are still largely based on national and local political ideologies which ignore the Pandits (Raina), so the only avenue left to them was to write their own stories and provide the world an insight into their concerns. These authors bring the indigenous Pandit voice in academic discourse and counter the traditional misrepresentation that their community had suffered. Their texts serve to preserve the cultural heritage of the Pandit community and ensure that traditional practices and customs continue to survive in the future. By articulating the wrongs done to them, these authors not only resist hegemony but also keep alive the memory of their traditional homeland for posterity. Thus, the scope of Indigenous Literature within contemporary Indian English literature extends to include recent Anglophone Kashmiri Pandit narratives. Armand Garnet Ruffo suggests that to facilitate the healing process of a suffering indigenous community, it is important to understand their "need for expression" (Ruffo 672). Pandit authors are instrumental in initiating the healing process for their community by addressing and articulating their historical trauma; their "need for expression" arises from the silence and marginalization that they had endured for so many years. As indigenous literary works, the Pandit narratives also serve to advance the cause for social 
justice and advocate the community's right to return to their native homeland. Ken Coates observes that linking contemporary struggles with the global indigenous peoples' movement can help in catching the media's attention; and hence, he argues, "labels and definitions" are important (Coates 10). Hence, by positioning the Pandit narratives within the scope of the global body of Indigenous Literature, this paper aims to offer new and alternative ways to understand and perceive the Kashmiri Pandit community and their history.

\section{References}

Abt, Teresa P. “Indigenous Literature of Australia, an Ambivalent Question of Self.” Rozmowy o Komunikacji. Ed. Grazyna Habrajska. Leksem: Lask, 2008. 171- 184. Print.

Baig, Muzaffar. "Pandits Original Inhabitants of Kashmir." Greaterkashmir.com. Greater Kashmir, 26 Feb. 2019. Web. 8 Oct. 2020.<https://www.greaterkashmir.com/news/india/pandits-originalinhabitants-of-kashmir-muzaffar-baig/>.

Bamzai, Prithivi Nath Kaul. Cultural and Political History of Kashmir: Modern Kashmir.

New Delhi: MD Publications Private Limited, 1994. Print.

Bose, Sumantra. Kashmir: Roots of Conflict, Paths to Peace. Cambridge: Harvard University Press, 2009. Print.

Chiu, Kuei-fen. “The Production of Indigeneity: Contemporary Indigenous Literature in Taiwan and Trans-cultural Inheritance." The China Quarterly 200 (2009):1071-1087. Print.

Coates, Ken S. Introduction. A Global History of Indigenous Peoples: Struggle and Survival. New York: Palgrave Macmillan, 2004. 1- 24. Print.

Dabla, Bashir Ahmad. Sociological Implications of Pandit Migration in Jammu and Kashmir. Srinagar: Jay Kay Book Shop, 2008. Print.

EFSAS. "The Exodus of Kashmiri Pandits." Efsas.org. European Framework for South Asian Studies, July 2017. Web. 6 Oct. 2020.<https://www.efsas.org/publications/study-papers/the-exodus-ofkashmiri-pandits/>.

Essa, Azad. "Kashmiri Pandits: Why We Never Fled Kashmir - Kashmir: The Forgotten

Conflict." Aljazeera.com. Al Jazeera, 8 Aug. 2011. Web. 28 Sept. 
2020.<https:/ / www.aljazeera.com/news/2011/8/2/kashmiri-pandits-why-we-never-fledkashmir>.

Gosart, Ulia. "Indigenous Peoples: Attempts to Define." Biomapping Indigenous Peoples. Ed. Susanne Berthier-Foglar et al. N.p.: Brill Rodopi, 2012. 87-116. Print.

Griffin, Peter. "Rahul Pandita On Kashmir and its Stories." Forbesindia.com. Forbes India, 27 Feb.2013. Web. 4 Oct. 2020.<https://www.forbesindia.com/article/recliner/rahul-pandita-on-kashmir-andits-stories $/ 34787 / 1>$.

Hakeem, Abdul. Paradise on Fire: Syed Ali Geelani and the Struggle for Freedom in Kashmir. Leicestershire: Revival Publications, 2014. Print.

IWGIA. "Indigenous Peoples in India." Iwgia.org. International Work Group for Indigenous Affairs, n.d. Web. 8 Oct.

2020.<https:/ / www.iwgia.org/en/india.html\#: :text=Indigenous \%20peoples\%20in\%20India\%20c omprise,which \%20are\%20not\%20officially\%20recognized.>

Kaw, Maharaj K. Kashmir and Its People: Studies in the Evolution of Kashmiri Society. New Delhi: APH Publishing, 2004. Print.

Lacombe, Michèle. “On Critical Frameworks for Analyzing Indigenous Literature: The Case of Monkey Beach." International Journal of Canadian Studies 41 (2010): 253-276. Print.

Nandy, Ashis. "Negotiating Necrophilia: An Afterword." Islam, Women, and Violence in Kashmir: Between India and Pakistan. By Nyla Ali Khan. New York: Palgrave Macmillan, 2010. 169174. Print.

Nelson, Joshua B. “The Uses of Indigenous Literatures.” World Literature Today 88.5 (2014): 28-32. Print.

Pandita, Rahul. Our Moon has Blood Clots: The Exodus of the Kashmiri Pandits. Noida: Random House India, 2013. Print.

Raina, Pamposh. "A Conversation With: Journalist and Author Rahul Pandita." India.blog.nytimes.com. The New York Times, 19 Feb. 2013. Web. 4 Oct.

2020.<https:/ /india.blogs.nytimes.com/2013/02/19/a-conversation-with-journalist-and-authorrahul-pandita/>.

Ruffo, Armand Garnet. “Why Native Literature?" American Indian Quarterly 21.4 (1997): 663- 673. Print.

Teng, M.K. \&Gadoo, C.L. Kashmir: Militancy and Human Rights. New Delhi: Anmol Publications, 1998. Print.

Tripathy, Abhinav. “Kashmiri Pandits: The Lost Identity.” Researchgate.com. Research Gate, n.d.: 18. Web. 20 Sept. 2020.<https://www.researchgate.net/publication/261857707_Kashmiri_Pandits_The_lost_identity $>$.

UN. “Indigeneous Peoples at the United Nations." UN.org. United Nations, n.d. Web. 6 Oct. 2020.<https://www.un.org/development/desa/indigenouspeoples/about-us.html>.

62

Litinfinite Journal is Indexed By MLA Directory Of Periodicals \& MLA International Bibliography, EBSCO, ProQuest, SCILIT, Ulrichsweb \& Ulrich's Periodicals Directory, ICI World Of Journals, J-Gate, JISC-Sherpa Romeo, DRJI, EuroPub \& Other Major Indexing Services. (This Open Access article is published under a Creative Commons Attribution Non-Commercial 4.0 International License.) 
UNPFII. “Who are Indigenous Peoples?.” UN.org. United Nations, n.d. Web. 8 Oct. 2020.<https:/ / www.un.org/esa/socdev/unpfii/documents/5session_factsheet1.pdf>.

WHO.“Indigenous Populations." WHO.int. World Health Organization, Dec. 2010. Web. 6 Oct. 2020.<https://www.who.int/topics/health_services_indigenous/en/>.

Zutshi, Chitralekha. Languages of Belonging: Islam, Regional Identity, and the Making of Kashmir. Delhi: Permanent Black, 2003. Print.

Soumyadeep Neogi is a Senior Research Fellow at the Department of English, University of Delhi, where he is currently pursuing his Ph.D. on the representation of the Kashmir conflict in literature. His broader research interests include Partition and South Asian Cultural Studies. 